\title{
The composition, trend and impact of urban solid waste in Beijing
}

\author{
Yi Xiao Xuemei Bai $\cdot$ Zhiyun Ouyang • \\ Hua Zheng • Fangfang Xing
}

Received: 19 April 2006 / Accepted: 31 December 2006/ Published online: 15 May 2007

(C) Springer Science + Business Media B.V. 2007

\begin{abstract}
This paper provides an overview of the trend of generation, composition, and management of municipal solid waste, and estimates the carbon emissions arising from municipal solid waste management in Beijing. The correlation analysis conducted shows that the generation of municipal solid waste in Beijing has been growing steadily, showing high correlations $(r>0.9)$ to the total GDP, per capita income, and the population. Food waste showed an increasing trend since 1990. Compared with the results of an investigation in 1990, ash and woodchips content in 2003 declined from $56 \%$ to $17 \%$, while the percentage of paper and plastic increased from $10 \%$ to $29 \%$ over the same period. The calorific value of the municipal waste also increased, from $2,686 \mathrm{~kJ} / \mathrm{kg}$ in 1990 to $4,667 \mathrm{~kJ} / \mathrm{kg}$ in 2003 , indicating that the waste is suitable for incineration. Currently, the source separation ratio of municipal waste is approximately $15 \%$. About $94 \%$ of all the collected solid waste goes to the landfill while $4 \%$ is composted and $2 \%$ is
\end{abstract}

Y. Xiao $\cdot$ Z. Ouyang $\cdot$ H. Zheng $\cdot$ F. Xing

State Key Lab of Systems Ecology,

Research Center for Eco-Environmental Sciences,

Chinese Academy of Sciences,

Beijing 100085, China

X. Bai $(\triangle)$

Urban Systems Program,

Commonwealth Scientific and Industrial

Research Organization,

GPO Box 284, Canberra, ACT 2601, Australia

e-mail: igesbai@yahoo.com incinerated. A moderate garbage collection fee is applied to both permanent and temporary residents in Beijing, but the willingness to pay for solid waste collection and treatment is still low. Under current treatment mode, the total amounts of carbon emission from waste disposal sites and incineration increased with the increase of municipal solid waste, from $29.8 \mathrm{Gg}$ in 1990 to $84.5 \mathrm{Gg}$ in 2003, including $83.3 \mathrm{Gg}$ of $\mathrm{CH}_{4}$ and $22.0 \mathrm{Gg}$ of $\mathrm{CO}_{2}$. The data availability and methodological challenges in monitoring the quantity and characteristics of municipal solid waste are discussed.

Keywords Municipal solid waste Carbon emission . Solid waste management $\cdot$ Beijing

\section{Introduction}

Rapid urbanization along with its increasing human activities in metropolitan areas imposes great challenges to urban environmental management. One of the most important environmental problems in cities is the production and containment of urban solid waste (Buenrostro and Bocco 2003; Pokhrel and Viraraghavan 2005). Global generation of municipal solid waste in 1997 was 0.49 billion tonnes with an estimated annual growth rate of $3.2-4.5 \%$ in developed nations and $2-3 \%$ in developing nations (Suocheng et al. 2001). Inappropriate management of urban solid waste not only increases the pollution 
to the environment, but also threatens human health through its collection, transfer and disposal processes. As China already produces $29 \%$ of the world's municipal solid waste each year (Dong et al. 2001), an integrated solid waste management system, including mechanisms of waste reduction, reuse, recycle and disposal, will be an important prerequisite for China's sustainable development. Industrialized countries such as Germany, Sweden, Japan, and the United States have already achieved remarkable results in comprehensive utilization of resources as well as solid waste management (Yuan et al. 2005).

Beijing is the capital of China, and the largest city in northern China. It covers an area of approximately $16,808 \mathrm{~km}^{2}$ with a total population of more than 13 million. The city consists of eight central and near-suburb districts (Dongcheng, Xicheng, Chongwen, Xuanwu, Chaoyang, Haidian, Fengtai, Shijingshan), eight far-suburb districts (Mentougou, Fangshan, Shunyi, Tongzhou, Changping, Daxing, Pinggu, Huairou,) and two far-suburb counties (Miyun, Yanqing). For the last two decades, Beijing has undergone a rapid economic development and urban expansion. The GDP growth rate exceeds $10 \%$ in the 5 years since 2000 . Per capita GDP reached US\$5,457 in 2005. Total population has grown $40.6 \%$ during the last two decades. Municipal solid waste has become one of the most serious environmental problems in Beijing, and a proper municipal solid management system is vital for the overall environmental management of Beijing ( $\mathrm{Li}$ et al. 1999). In addition, the high rate of dominant landfill in Beijing makes it important to consider a proper management of greenhouse gas emission throughout the process.

This paper aims to provide an overview on Beijing's urban solid waste management with regard to its generation, composition, characteristics, and management; estimate global impacts arising from the management, e.g., carbon emissions from municipal solid waste disposal sites and incineration, and to identify major challenges in solid waste management research and practice in Beijing.

\section{Generation and trend of municipal solid waste}

Figure 1 shows the actual amount of disposed solid waste over the last decades. It can be seen that the amount of solid waste has increased steadily over the 14 years, from 220.0 thousand tonnes in 1990 to $3,613.6$ thousand tonnes in 2003, with an rate of increase of $58.3 \%$ during this period.

Rapid economic and population growth contribute to the generation of solid waste. The amount of municipal solid waste generated in Beijing has increased with the growth of economy and urban population. The generation of municipal solid waste in Beijing shows significant correlations with the GDP $(r=$ $0.96, p<0.01)$, per capita income $(r=0.92, p<0.01)$, and the population $(r=0.93, p<0.01)$ (Figs. 2, 3, 4). A multi-regression analysis shows that, among these three, GDP has been identified to be the strongest explanatory factor for the growth of the total solid waste amount in Beijing, indicating that the environment has been paying the price for the economic growth. Influenced by the economical development and population increase, municipal solid waste has been growing gradually. However, solid waste generation per capita does not seem to correlated to per capita income from 1990 to 2003 $\left(\mathrm{Y}=-2 \mathrm{E}-09 \mathrm{x}^{2}+2 \mathrm{E}-05 \mathrm{x}+1.1562 \mathrm{R}^{2}=0.6755\right)$ From 1990 to 1995 , solid waste generation per capita
Fig. 1 Generation of urban solid waste between 1990 and 2003 in Beijing. Source: Beijing Statistics Bureau (1990-2003)

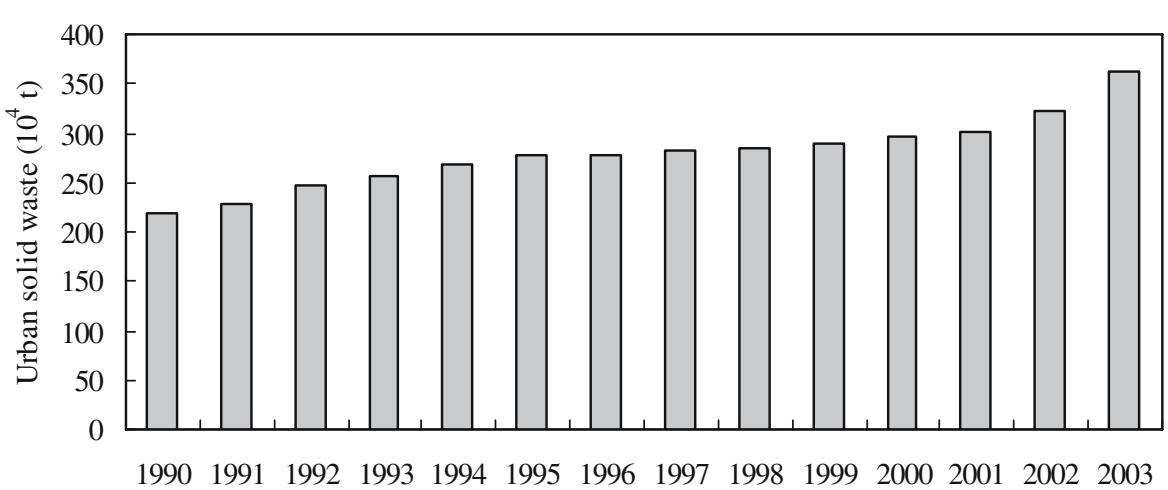




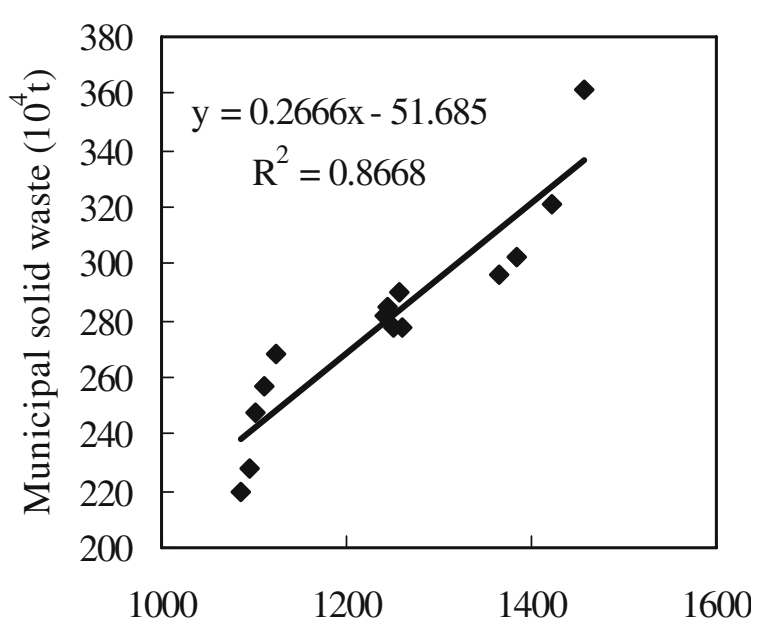

Population $\left(10^{4}\right.$ capita)

Fig. 2 Relationship between municipal solid waste generation and population from 1990 to 2003. Source: Beijing Statistics Bureau (1990-2003)

increased gradually with the increase of per capita income, but it decreased with the increase of per capita income from 1995 to 2005 (Fig. 5). The inversed U shape mainly resulted from the change of Beijing's energy structure. After 1995, coal, as a heating fuel, was gradually replaced by natural gas. From 1996 to 2000 , the number of natural gas users increased from $3.95 \times 10^{5}$ households to $1.34 \times 10^{6}$ households http:// china5e.com/dissertation/naturalgas/0058.htm). As a

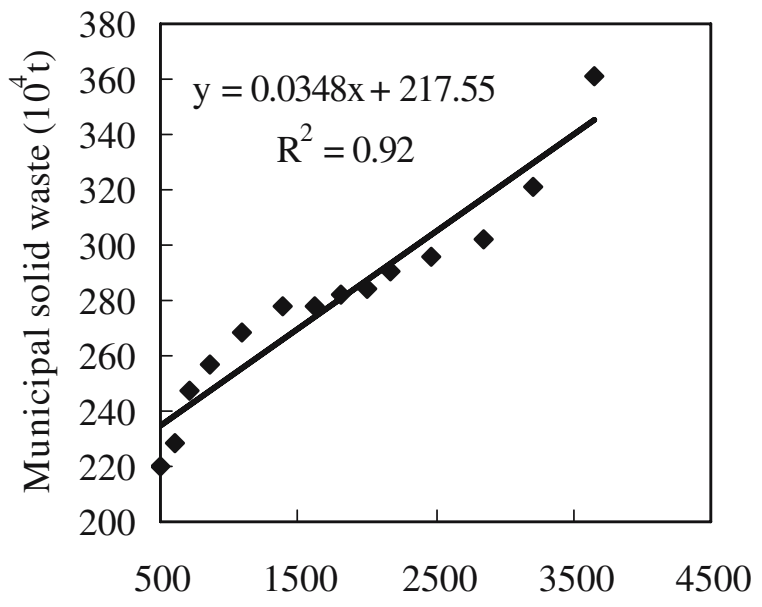

Gross domestic production $\left(10^{8}\right.$ yuan $)$

Fig. 3 Relationship between municipal solid waste generation and GDP from 1990 to 2003. Source: Beijing Statistics Bureau (1990-2003)

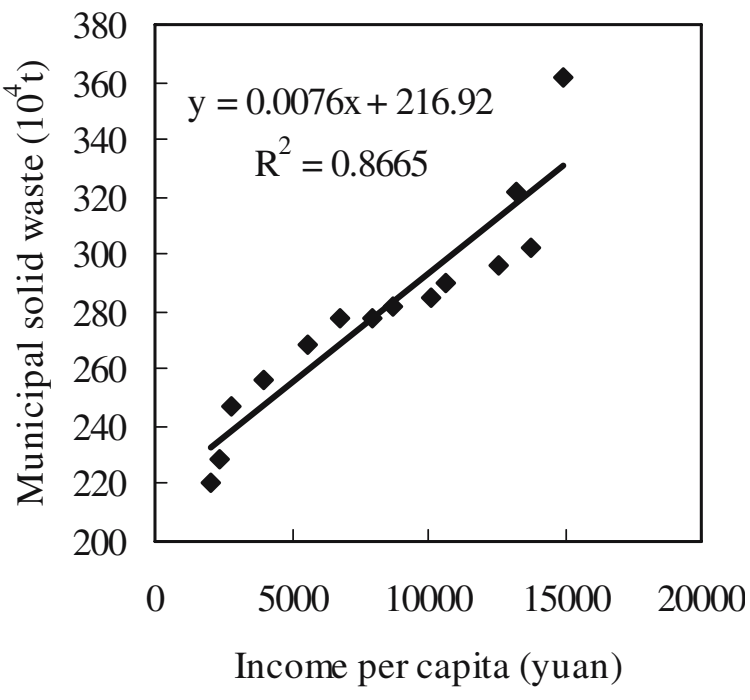

Fig. 4 Relationship between municipal solid waste generation and per capita income from 1990 to 2003. Source: Beijing Statistics Bureau (1990-2003)

result, coal ash, a main component of municipal solid waste, declined significantly (Table 1).

\section{Composition of urban solid waste}

Table 1 shows the composition and typical percentage distribution of solid waste in Beijing from 1990 to 2003. Solid waste composition has been found to be

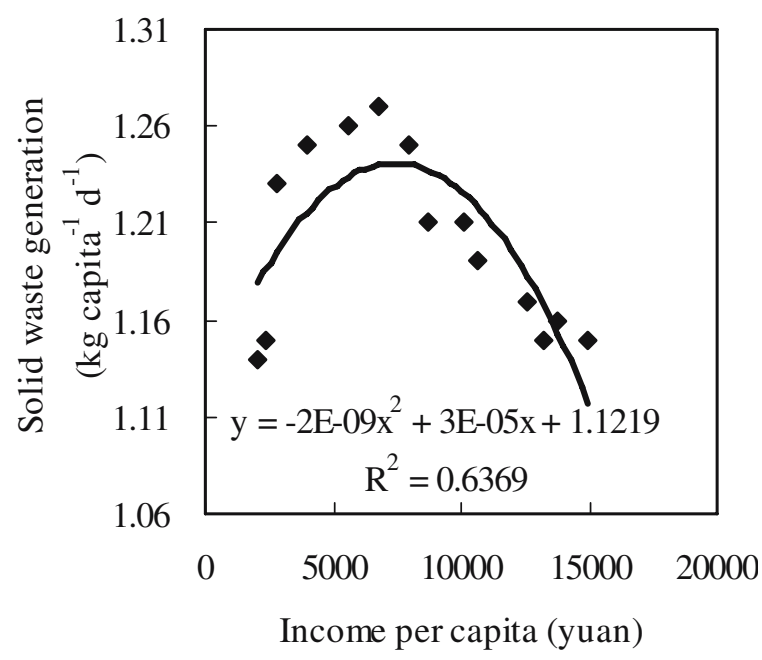

Fig. 5 Relationship between average solid waste generation and per capita income from 1990 to 2003. Sources: Beijing Statistics Bureau (1990-2003); Zhou et al. (2003, 2004) 
Table 1 Composition (\%) of urban solid waste from 1990 to 2003 in Beijing

\begin{tabular}{rlrlrrrrrrrr}
\hline Year & Food waste & Plastic & Brick and tile & Wood & Glass & Paper & Fiber & Ash & Metal & Others & Data source \\
\hline 1990 & 24.89 & 5.08 & 4.11 & 4.13 & 3.10 & 4.56 & 1.82 & 52.22 & 0.09 & - & Wang 2000 \\
1995 & 35.96 & 10.35 & 1.50 & 8.37 & 10.20 & 16.18 & 3.56 & 10.92 & 2.96 & - & Wang 2000 \\
2000 & 44.2 & 13.60 & 0.88 & 7.47 & 6.34 & 14.30 & 9.58 & 2.02 & 1.17 & 0.5 & Li et al. 2005 \\
2003 & 48.00 & 10.29 & 2.41 & 8.04 & 2.30 & 18.28 & 1.83 & 8.54 & 0.26 & 0.05 & Sun et al. 2006 \\
\hline
\end{tabular}

relatively stable. Food waste always comprises the highest proportion except in 1990, and its representation has an increasing trend. Plastic, paper and ash also occur in relatively high proportions.

From 1990 to 2003, the proportion of organic substances (food waste, paper, plastic, wood and fiber) increased gradually, and accounted for $86 \%$ in 2003. Meanwhile, the proportion of recycling waste (plastic, glass, paper, fiber and metal) also increased, from $15 \%$ in 1990 to $45 \%$ in 2000 . However, it decreased in 2003 due to the increase of food waste.

Municipal solid waste treatments include recycling, composting and combustion (Rong 2004). The content of organic substance in municipal solid waste is an important indicator of waste quality, which often determines the treatment technology to use. Waste with high content of organic substance favors treatment by composting and incineration. From Table 1, it is obvious that the proportion of organic substances and the volume of recyclable substances in the waste increased from 1990 to 2003 in Beijing. The net calorific value in 1990 in Beijing was only $2,686 \mathrm{~kJ} / \mathrm{kg}$, lower than the net calorific value $(>3,349 \mathrm{~kJ} / \mathrm{kg})$ for incineration (Chen et al. 2000). However, as living quality improved, the calorie level kept rising (White paper on the domestic garbage disposal in Beijing 2004). In 2003, the calorie level reached $4,667 \mathrm{~kJ} / \mathrm{kg}$, which provided the conditions for composting and incineration.

\section{Municipal solid waste management}

In 2004, there were 22 treatment establishments for solid wastes in Beijing, 5 transfer stations, 13 sanitary landfills, 2 compost and 2 incinerators. The designed treatment capacity was 9,850 t/day (Sun et al. 2006). However, the treatment capacity of treatment establishments proved insufficient because the total capacity of the treatment establishments could not satisfy the need of municipal solid waste treatment in Beijing. Many of establishments must have been over-utilized to exceed their designed capacity as pollution-free facilities. Among the 13 treatment establishments in central and near-suburb districts (Fig. 6), the average ratio of actual treated amount and designed treatment capacity exceeded $90 \%$, and 10 of them surpassed $100 \%$ (Sun et al. 2006). For example, Gaoantun sanitary landfill was operated at a load of $197 \%$. As a result of these abnormal operations, the life span of these landfill establishments could be greatly shortened.

The proportions of sanitary landfill, composting and incineration in 2004 were 94\%, 4\% and 2\%, respectively. Sanitary landfill was the main treatment approach of municipal solid waste, and there was almost no composting or incineration available. Compared to the national level in 2003, Beijing was 6 points higher in terms of sanitary landfill, and almost 5 points lower in incineration (Table 2). In addition, the current source separation ratio of municipal waste is approximately $15 \%$ (White paper on the domestic garbage disposal in Beijing 2004), and this level clearly needs to be improved further.

In regard of financing, the sanitary disposal capacity of Beijing municipal solid waste has increased dramatically. In 2003, the sanitary disposal capacity of municipal solid waste was 2.6 times that in 2000 (Fig. 7). However, this treatment configuration poses challenges to the land availability surrounding Beijing. The traditional landfill practice produces various landfill gases such as methane, carbon dioxide, carbon monoxide, nitrogen, hydrogen sulfide and ammonia (Pokhrel and Viraraghavan 2005) The percentage of greenhouse gases (methane and carbon dioxide: $40-60 \%$ ) is high (Tchobanoglous et al. 1993). Some of these gases have a pungent odor (ammonia and hydrogen sulfide) and are poisonous. If a proper collection or venting system is not provided, these hazardous fumes can create a health risk for the population near the landfill (Pokhrel and Viraraghavan 
Fig. 6 Distribution of Beijing municipal solid waste disposing stations. The figure only shows the establishments distributed in 8 central and near-suburb districts. DT_TS Datun Transfer Station, YMK_TS Yamenkou Transfer Station, BTT_LFS Beitiantang Land Fill Station, MJL_TS Majialou Transfer Station, $N G \_C S$ Nangong Compost Station, XWJ_TS Xiaowuji Transfer Station, AD_LFS Anding Land Fill Station, BSS_LFS Beishenshu Land Fill Station, GAT_LFS Gaoantun Land FIll Station, $A S W \quad L F S$ Asuwei Land Fill Station, LLT_LFS Liulitun Land Fill Station, WLJ_TS Wuluju Transfer Station, JJP_LFS Jiaojiapo Land Fill Station. Source: Sun et al. 2006

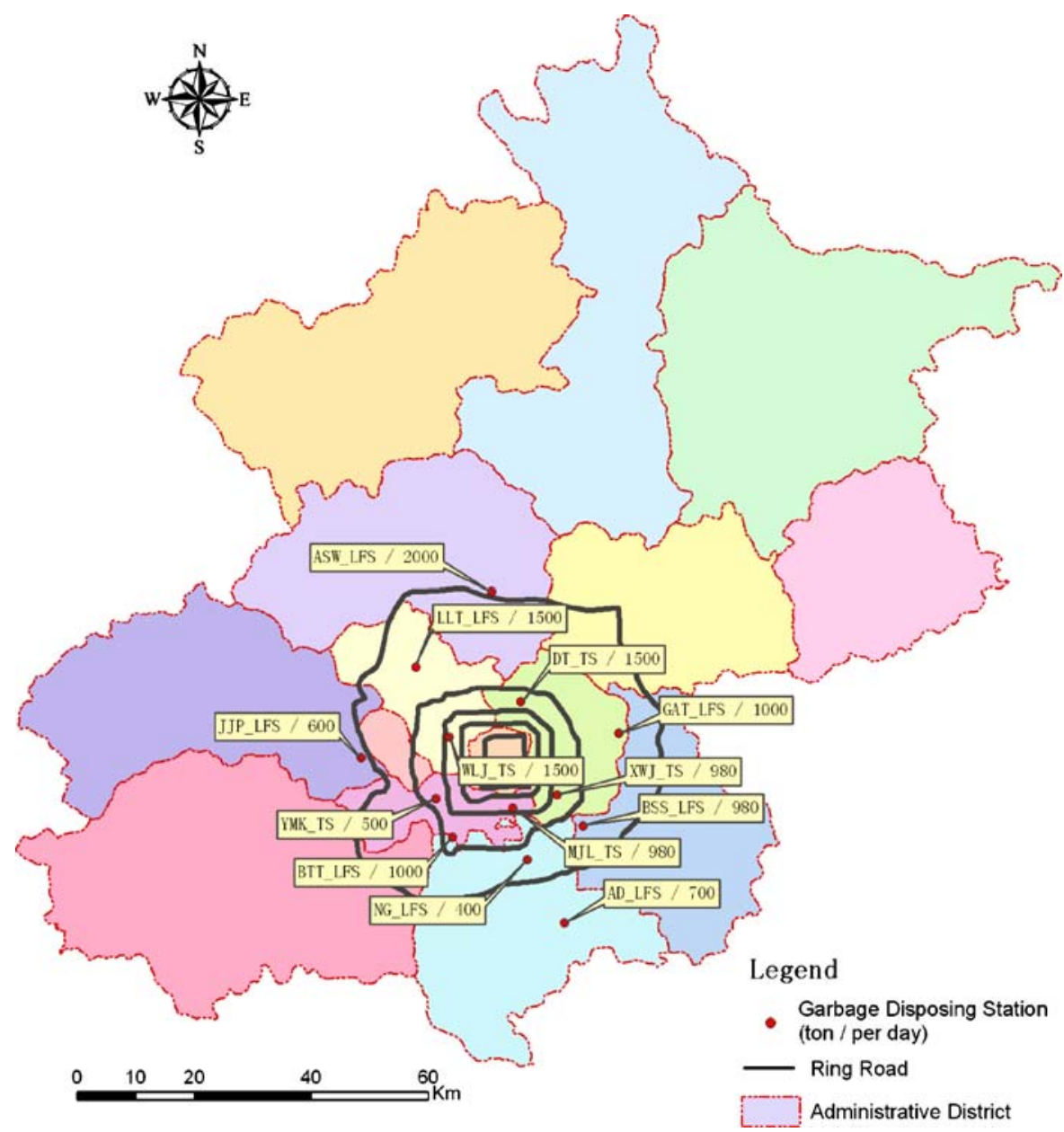

2005). In Beijing, it was not clear what was the composition of the gas produced from the landfill, nor what the health effects were on employees of the facility who are exposed to the landfill, or the effects on the population nearby. Among the landfill stations, only Asuwei sanitary landfill and Beishenshu sanitary landfill were designed to collect methane. Such poor

Table 2 Disposal of municipal solid waste in Beijing

\begin{tabular}{|c|c|c|c|}
\hline Treatment approaches & $\begin{array}{l}\text { Sanitary } \\
\text { landfill }\end{array}$ & Composting & Incineration \\
\hline Establishment & 13 & 2 & 2 \\
\hline Disposal in $2004\left(10^{4} \mathrm{t}\right)$ & 368.2 & 17.5 & 7.1 \\
\hline $\begin{array}{l}\text { Proportion (\%) in } 2004 \\
\text { in Beijing }\end{array}$ & 94 & 4 & 2 \\
\hline $\begin{array}{l}\text { Proportion (\%) in } 2003 \\
\text { in China }\end{array}$ & 88 & 5.1 & 6.9 \\
\hline
\end{tabular}

Data Source: Sun et al. (2006) management can lead to the deterioration of ground and surface water quality as well as land contamination. The report 'Geological environment investigation of dumps in Beijing' indicated that sanitary landfill capacity of garbage was very poor in Beijing suburb counties. Currently, only $33.3 \%$ of sanitary landfill was in suburb counties. There exist 121 dumps within the scope of Beijing water resource protection area, and $86 \%$ of them distributed in suburb counties (Sun et al. 2006).

As to waste fees, three kinds of fees are being charged on individual bases and/or at entity level: regular cleaning and maintenance fee, charged by relevant cleaning companies or property management companies or organizations; the city domestic garbage disposal fee, at 2 or 3 Yuan per household per month depending on residency status, collected by relevant community neighborhood committees or community property management companies appointed by com- 


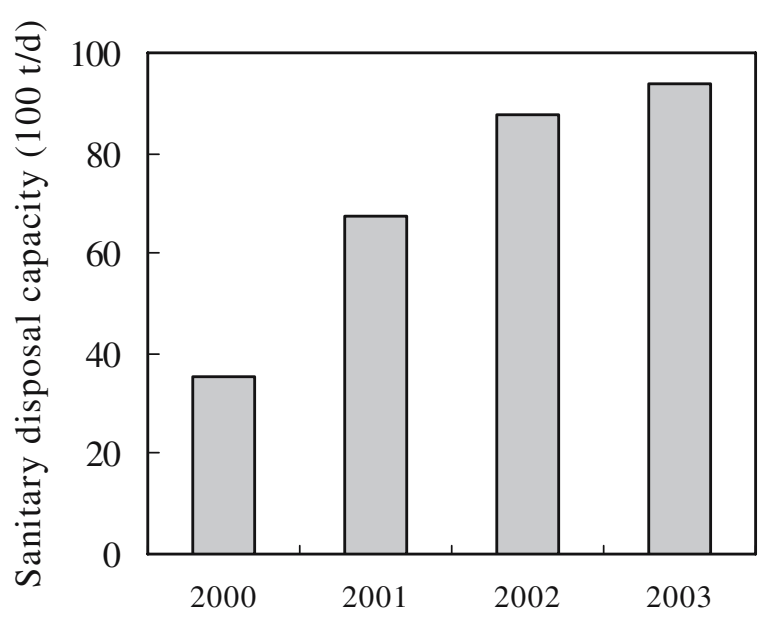

Fig. 7 Sanitary disposal capacity of urban solid waste form 2000 to 2003 in Beijing Source: Beijing Statistics Bureau (1990-2003)

mission; the entrusted cleaning and transporting fee, at 25 Yuan per ton, charged by relevant cleaning and transporting companies upon the entrusters. Up to 2008, the construction of municipal solid waste disposal establishments in Beijing will cost as much as 3,200 million Yuans, which will be far more than the fees collectable (White paper on the domestic garbage disposal in Beijing 2004).

\section{Carbon emission of Beijing Municipal solid waste management}

In addition to various local environmental problems discussed above, municipal solid waste management has global environmental implications as well. For example, $\mathrm{CH}_{4}$ emitted from landfill is one of major greenhouse gases, which has a much higher greenhouse effect than $\mathrm{CO}_{2}$. It has been estimated that $\mathrm{CH}_{4}$ emission from landfills worldwide accounts for 6$18 \%$ of total $\mathrm{CH}_{4}$ emissions ( $\mathrm{Yu}$ 1997). A study indicated that the carbon flow in Beijing's food chain showed a V-shape over the last 30 years with a sharp decrease in food carbon consumption per capita until the early 1990s, followed by a sharp increase after that (Luo et al. 2005). This change is due to a decrease in carbohydrate consumption along with an increase in meat consumption. This study also pointed out that the per capita food carbon consumption level might not yet be maximized, and will continue climbing. Considering that over $90 \%$ of all solid waste goes to landfill, it is of particular importance to take the $\mathrm{CH}_{4}$ emission from landfill into account in solid waste management in Beijing.

The carbon emission from solid waste management in Beijing was calculated using the IPCC guidelines (Intergovernmental Panel on Climate Change 2001). The estimation includes two parts: $\mathrm{CH}_{4}$ emission from landfill and $\mathrm{CO}_{2}$ emission from incineration.

$\mathrm{CH}_{4}$ emissions from solid waste disposal sites In IPCC, two methods were introduced: default method and First Order Decay (FOD) method. The default method was selected to estimate $\mathrm{CH}_{4}$ emission from solid waste disposal sites due to absence of historical data of waste quantity, composition and disposal practices for decades. The default method is based on the following equation:

$\mathrm{CH}_{4}$ emissions $(\mathrm{Gg} / \mathrm{yr})=\left[\left(\mathrm{MSW}_{\mathrm{T}} \cdot \mathrm{MSW}_{\mathrm{F}} \cdot \mathrm{L}_{0}\right)-\mathrm{R}\right](1-\mathrm{OX})$

Where

MSW $_{\mathrm{T}}$ Total MSW (municipal solid waste) generated (Gg/year)

$\mathrm{MSW}_{\mathrm{F}} \quad$ Fraction of MSW disposed at SWDS (solid waste disposal sites)

$\mathrm{L}_{0} \quad$ Methane generation potential [MCF.DOC.DOC ${ }_{\mathrm{F}} \cdot \mathrm{F} \cdot 16 / 12\left(\mathrm{Gg} \mathrm{CH}_{4} / \mathrm{Gg}\right.$ waste)]

MCF Methane correction factor (fraction)

DOC Degradable organic carbon [fraction ( $\mathrm{Gg} \mathrm{C}$ / Gg MSW)]

$\mathrm{DOC}_{\mathrm{F}} \quad$ Fraction DOC dissimilated

$\mathrm{F} \quad$ Fraction by volume of $\mathrm{CH}_{4}$ in landfill gas

$\mathrm{R} \quad$ Recovered $\mathrm{CH}_{4}$ (Gg/year)

OX Oxidation factor (fraction)

The relevant parameter values were selected according to IPCC guidelines (Table 3)

Estimating CO2 emissions from waste incineration The following method was selected to estimate $\mathrm{CO} 2$ emissions from waste incineration.

$\mathrm{CO} 2$ emissions $(\mathrm{Gg} /$ year $)=\mathrm{IW} \cdot \mathrm{CCW} \cdot \mathrm{FCF} \cdot \mathrm{EF} \cdot 44 / 12$

Where:

IW Amount of incinerated municipal solid waste (Gg/year)

CCW Fraction of carbon content in municipal solid waste (default is 0.4 ) 
Table 3 Selected parameter values for estimating $\mathrm{CH}_{4}$ emissions from solid waste disposal sites

\begin{tabular}{lllllll}
\hline Parameter & MSW $_{\mathrm{F}}$ & $\mathrm{MCF}$ & $\mathrm{DOC}_{\mathrm{F}}$ & $\mathrm{F}$ & $\mathrm{R}$ & $\mathrm{OX}$ \\
\hline Value & 0.9 & 0.4 & 0.55 & 0.5 & 0 & 0.1 \\
\hline
\end{tabular}

See text for explanation of column headings

FCF Fraction of fossil carbon in municipal solid waste (default is 0.4 )

EF Burn out efficiency of combustion of incinerators of municipal solid waste (fraction) (default is 0.95)

44/12 Conversion ratio from $\mathrm{C}$ to $\mathrm{CO}_{2}$

The results showed that the amount of $\mathrm{CH}_{4}$ emissions increased gradually with the increase of municipal solid waste. In $1990, \mathrm{CH}_{4}$ emissions from solid waste disposal sites was $21.92 \mathrm{Gg}$, while it became $83.31 \mathrm{Gg}$ in 2003 (Fig. 8). The composition of municipal solid waste was another factor which impacts its $\mathrm{CH}_{4}$ emission in addition to the amount of municipal solid waste. The $\mathrm{CH}_{4}$ emission is correlated with organic carbon content of easily decomposed municipal solid waste.

Similarly, the amount of $\mathrm{CO}_{2}$ emission from municipal solid waste incineration was also increased with the amount of municipal solid waste. In 1990, the amount of $\mathrm{CO}_{2}$ emission accounted for $49.05 \mathrm{Gg}$, while in 2003 it was $80.56 \mathrm{Gg}$ (Fig. 9). Although the

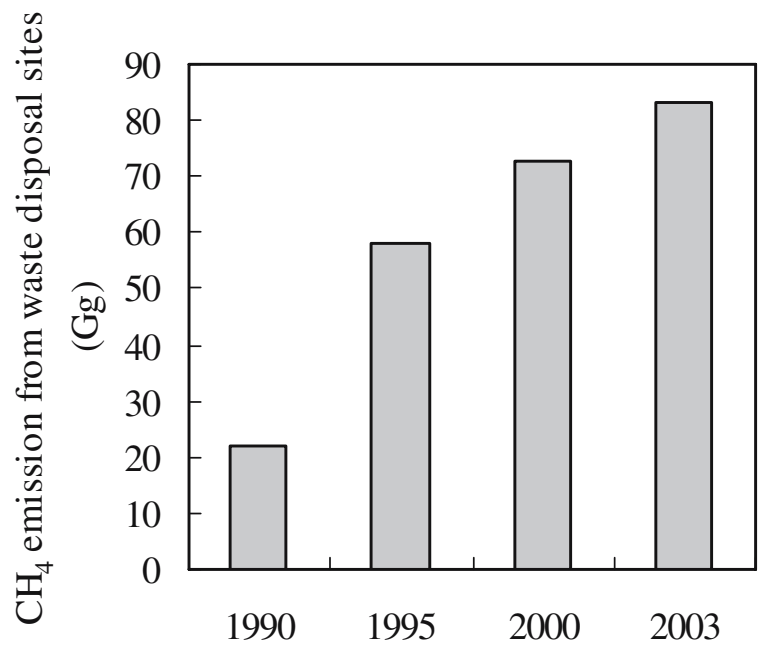

Fig. $8 \mathrm{CH}_{4}$ emissions from waste disposal sites proportion of municipal solid waste disposed by composting and incineration was less than $10 \%$ in Beijing, $\mathrm{CO}_{2}$ emission from Beijing municipal solid waste incineration should not be neglected. The increased $\mathrm{CO}_{2}$ emission attributes to an increase of municipal solid waste amount as well as its carbon content. From Table 1, the increase of organic substance content will enhance $\mathrm{CH}_{4}$ and $\mathrm{CO}_{2}$ emission.

The amount of $\mathrm{C}$ emission from waste disposal sites and incineration was similar to those of $\mathrm{CH}_{4}$ and $\mathrm{CO}_{2}$ emissions (Fig. 10). In 2003, C emission accounted for $84.45 \mathrm{Gg}, 2.8$ times that in 1990. With the increase of the amount and carbon content of municipal solid waste (Fig. 1; Table 1), C emission rises gradually through sanitary landfill and incineration. As to the proportion of $\mathrm{C}$ from $\mathrm{CH}_{4}$ and $\mathrm{CO}_{2}$, it was determined by the disposing measures, such as sanitary landfill and incineration. For example, applying incineration technology will increase $\mathrm{CO}_{2}$ emission, and decrease $\mathrm{CH}_{4}$ emission accordingly.

\section{Discussion}

Future challenges and policy recommendations

The solid waste management in Beijing has been greatly improved during the past decade. However, challenges remain in respect of domestic garbage reduction, resource utilization, pollution-free treatment and industrialization.
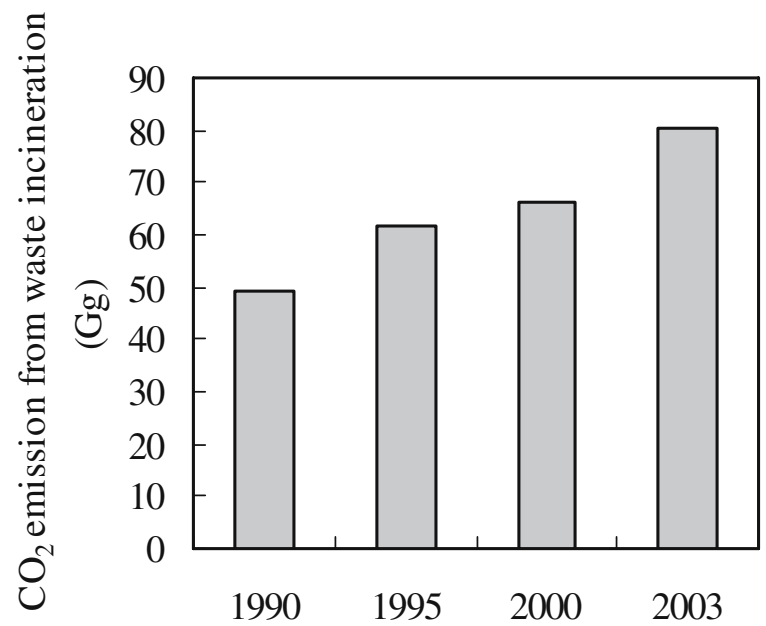

Fig. $9 \mathrm{CO}_{2}$ emissions from waste incineration 


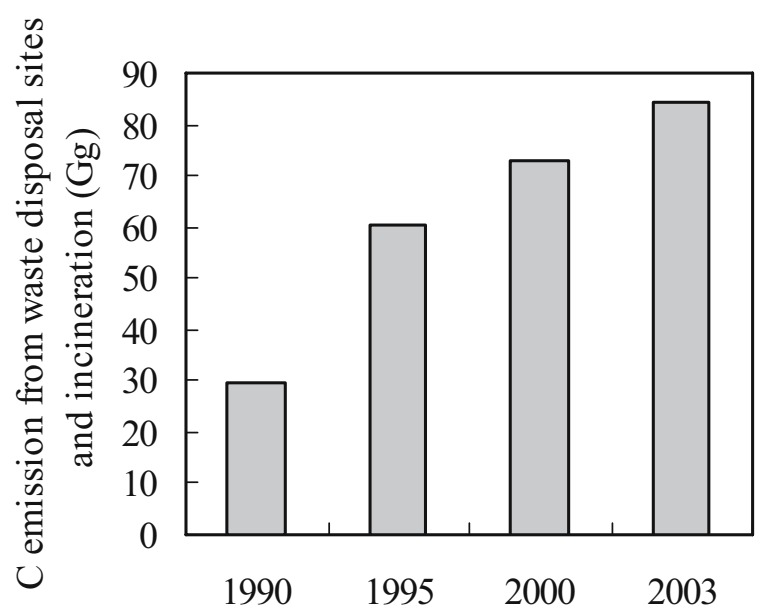

Fig. 10 Carbon emissions from waste disposal sites and incineration

Waste minimization will remain one of the major challenges and needs to be implemented more strictly. Currently, there is no limitation on the amount of residential solid waste. Residential solid waste is currently charged at a fixed rate per household for the generation/collection (3 Yuan per household per month), and there is no limitation/control on the actual quantity or volume of solid waste generated. As Bai and Sutanto (2002) analyzed, even if the regulation is revised and solid waste is to be charged on the basis of weight/volume (i.e. "Pay-As-YouThrow"), the regulation can be difficult to implement because the quantity of solid waste from each individual household is difficult to measure. The convenience of waste discarding, to a certain extent, is also responsible for more solid waste generation. People tend to throw out serviceable goods simply because they are old or outdated, and there is no additional cost for their discharge. It is therefore important to call for discipline and good social norms, and to boost public awareness and self-consciousness of the problems in solid waste management (Bai and Sutanto 2002). Improving the waste fee levying system may be helpful in providing financial support for the existing urban solid waste disposal facilities and finance programs as well as reducing the quantity of urban solid waste generated. In addition, sourceseparated collection is an effective approach to reduce solid waste. For example, before incineration, biological or mechanical treatment, solid waste is limited to landfill in Germany. Mongkolnchaiarunya (2005) also reported a successful story of an incentive program 'Garbage for Egg' launched in Yala municipality, Thailand. A total of 66.8 tons of recyclable waste was collected from the local area through this program (Mongkolnchaiarunya 2005). In fact, sorting refuse before collection will reduce the amount of solid waste produced and facilitate the recycling of materials as well as reducing the overall cost of waste disposal. However, efficient and effective separation and collection of solid waste materials require different methodologies due to different economic situations in different districts.

Efficiently integrated waste management system should be implemented to reduce the quantity of urban solid waste, decrease moisture content and increase the net caloric value. Besides sanitary landfill, composting and incineration, another important treatment approach is integrated treatment. That is to say, based on classification, two or more measures are adopted. Integrated treatment is better than the single disposal approach, such as incineration, composting and sanitary landfill due to heterogeneous characteristics within municipal solid waste. As a result, combined with restricting original garbage, treatment approaches of composting and incineration should be popularized gradually, which will also be helpful in the protection of limited land resources. The current proportions of urban solid waste disposed by different approaches are not ideal. Only a small percentage of municipal solid waste is composted and a small percentage of waste is burnt in Beijing. The percentage of solid waste managed by composting or burning is insignificant compared to the amount of waste generated every day. In 2004, the proportions of sanitary landfill, composting and incineration are $94 \%, 4 \%$ and $2 \%$, respectively, for Beijing municipal solid waste treatment. Sanitary landfill remains the main treatment approach to municipal solid waste treatment.

Altogether, the whole process management system for municipal solid waste needs to be designed in order to enforce their management, including conception transition, sort collection, integrated disposal and policy guarantee. Thapa (1998) also suggested that the collection of a service fee, involvement of the private sector in waste management, environmental awareness building in public and the enforcement of stringent environmental legislation were necessary for sustainable management of solid waste. 
Data availability and methodological challenges of monitoring the quantity and characteristics

Municipal solid waste management is vital for the urban sustainable development and it is usually based on quantity and quality of the basic data. In this study, the data of urban solid waste generation, urban sanitary disposal capacity, population, gross domestic production, and income per capita were cited from the Beijing Statistical Yearbooks (1990-2003). Other data, including the per capita solid waste generation, data for solid waste composition, and data for municipal solid waste disposal sites and capacity, were cited from various existing literature.

In fact, these environmental data are very difficult to obtain, especially the data on municipal solid waste composition. The reason for this is that many data are not published or not made accessible to the public. Currently, Beijing Solid Waste Administration Department carries out the investigation on the generation, composition and characteristics of Beijing municipal solid waste every year. However, the data are not issued timely and are not shared with the public. Many data can only obtained from published reports by Beijing Solid Waste Administration Department, and it is very difficult to keep the data up-todate when others want to collect relatively new relevant data. In addition, it is also very difficult to do further analysis on the municipal solid waste data because many details were not explained in the published literature, such as sampling site setting, sample quantity, sampling time, etc. Boyle (2000) also suggested that comprehensive waste data is scarce and reliability cannot often be determined. In the future, more collaborative researches must be conducted among independent scientists and government departments. Research data must be shared with the public so that the public awareness of these environmental issues can be improved. This will eventually benefit government agencies themselves. Currently, there exist two approaches to obtaining the data of municipal solid waste in Beijing, dump trucks and actual weight. The former may overestimate the amount when trucks are fully loaded. Therefore, actual weight should be a better method than dump truck estimation in calculating municipal solid waste generation. In this study, the data by actual weight were selected.

For the composition of municipal solid waste, there also exist many approaches to obtaining the data, such as actual measurement, sort calculation, and modeling prediction. In practice, sort calculation was usually used to estimate their composition, and this method was selected in the present study. At first, sufficient sub-samples were selected according to garbage collection stations located in different districts, and then they were classified. Then, the composition of municipal solid waste was calculated through the classified data and the data of garbage collection stations. Potential errors are easily produced due to the heterogeneous characteristics of the municipal solid waste. To decrease the errors, sufficient sub-samples must be selected, and sampling must satisfy the demand of statistics. In addition, prediction models can be an effective approach to analyzing the generation and composition of municipal solid waste. However, it must be based on the amounts of exactly historical data, including the relevant data needed to design models. To strengthen the monitoring of municipal solid waste is crucial for the effective management in Beijing.

\section{Conclusions}

Rapid economic and population growth has caused tremendous increases of solid waste generation in Beijing, for which GDP is the strongest explanatory factor among the three factors, GDP, per capita income and population. From 1990 to 2003, the proportion of organic substances, the volume of recyclable substances and the calorific value of the municipal solid waste increased in Beijing. With the increase of the amount and carbon content of municipal solid waste, carbon emission rose significant through sanitary landfill and incineration. Future challenges include: (1) the implementation of an effective waste minimization program; (2) systematic urban solid waste management; and (3) improvement in data availability and methodology in monitoring the quantity and characteristics of municipal solid waste.

Acknowledgment We acknowledge the financial support from the National Basic Research Program of China (2005CB724206).

\section{References}

Bai, R., \& Sutanto, M. (2002) The practice and challenges of solid waste management in Singapore. Waste Management, 22, 557-567. 
Beijing Statistics Bureau (1990-2003). Beijing statistical yearbook from 1990 to 2003. Beijing: China statistics press, (In Chinese).

Boyle, C. A. (2000). Solid waste management in New Zealand. Waste Management, 20, 517-526.

Buenrostro, O., \& Bocco, G. (2003). Solid waste management in municipalities in Mexico: Goals and perspectives. Resources Conservation \& Recycling, 39, 251-263.

Chen, L. Y., Zhong, S. S., Pan, Z. S., \& Qing, Y. J. (2000), Composition and treatment strategies of Hongkong, Guangzhou, Foshan and Beijing municipal solid waste. Environmental Science, 18(2), 58-61, (in Chinese).

Dong, S. S., Tong, K. W., \& Wu, Y. P. (2001) Municipal solid waste management in China: Using commercial management to solve a growing problem. Utilities Plicy, 10, 7-11. http://china5e.com/dissertation/naturalgas/0058.htm (in Chinese).

Intergovernmental Panel on Climate Change (2001). Good Practice Guidance and Uncertainty Management in National Greenhouse Gas Inventories. Chapter 5, Waste. http://www.ipcc-nggip.iges.or.jp

Li, G. X., Huang, B., \& Jiang, H. (1999). Investigation and Evaluation on Treatment and Utilization of Beijing Municipal Garbage. Journal of China Agricultural University, 4, 103-108 (In Chinese).

Li, Y. C., Li, Y. F., Rong, B., \& Liu, X. (2005). Status and problems analysis of MSW composting in Beijing. Environmental Sanitation Engineering,13(4), 24-28, (in Chinese).

Luo, T., Ouyang, Zh., Wang, X., Miao, H.,\& Zheng, H. (2005). Dynamics of Urban Food-carbon Consumption in Beijing Households. Acta Ecologica Sinica,25(12), 3252-3258, (In Chinese).

Mongkolnchaiarunya, J. (2005). Promoting a community-based solid waste management initiative in local government: Yala municipality, Thailand. Habitat International,29(1), 27-40.

Pokhrel, D., \& Viraraghavan, T. (2005). Municipal solid waste management in Nepal: Practices and challenges. Waste Management, 25, 555-562.
Rong, B., Wei, P. M., Li, Y. F., \& Li, Y. C. (2004). Composition Analysis to Beijing's Domestic Refuse and Corresponding Treatment Countermeasure. Environmental Protection,10, 30-33, (In Chinese).

Sun, J., Lv, Z. Q., Zhang, Y. M., \& Liu, X. G. (2006). Treatment strategies of Beijing municipal solid waste. Chinese Journal of Urban Environmental Sanitation,2, 33-37.

Suocheng, D., Tong, K. W., \& Yuping, W. (2001). Municipal solid waste management in China: Using commercial management to solve a growing problem. Utilities Policy, 10, 7-11.

Tchobanoglous, G., Theisen, H., \& Vigil, S. (1993) Integrated solid waste management: Engineering principles and management issues. McGraw-Hill, New York, USA. pp. 282-283.

Thapa, G. B. (1998). Lessons learned from solid waste management in Kathmandu, Nepal. Habitat International, 22(2), 97-114.

Wang, W. P. (2000) Research on solutions to domestic solid waste in cities of China. Journal of Natural Resources, 15 (2), 128-132 (In Chinese).

White paper on the domestic garbage disposal in Beijing (2004). Chinese Journal of Urban Environmental Sanitation, 1, 9-12 (In Chinese).

Yu, G. (1997). Methane emission from urban solid waste. Progresses in Environmental Science,15(2), 67-74 (In Chinese).

Yuan, H., Wang, L. A., Su, F. W., \& Hu, G. (2005). Urban solid waste management in Chongqing: Challenges and opportunities. Waste Management, (in press). dio: 10. 1016/j. wasman. 2005. 09. 005.

Zhou, C. H., Lu, M. X., Wu, W. W., \& Bai, R. (2003) Prediction of municipal solid waste output in Beijing. Journal of China University of Mining \& Technology, 32 (2), 169-172, (In Chinese).

Zhou, C. H., Lu, M. X., \& Wu, W. W. (2004). On prediction of municipal solid waste classification in Beijing. Journal of Safety and Environment, 4(5), 37-40 (In Chinese). 